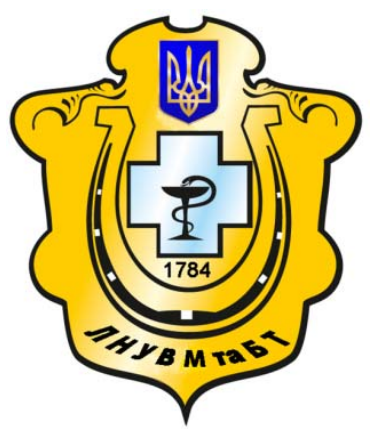

Науковий вісник Львівського національного університету ветеринарної медицини та біотехнологій імені С.З. Гжицького

Scientific Messenger of Lviv National University of Veterinary Medicine and Biotechnologies named after S.Z. Gzhytskyj

doi:10.15421/nvlvet7006

ISSN 2413-5550 print

ISSN 2518-1327 online

http://nvlvet.com.ua/

УДК 619:636.1

\title{
Лікувально-профілактичні заходи при герпесвірусній інфекції коней першого типу
}

\author{
О.Є. Галатюк, В.Л. Бегас \\ halatyuk@mail.ru

\begin{abstract}
Житомирський національний агроекологічний університет, Старий бульвар, 7, м. Житомир, 10002, Україна
\end{abstract}

\begin{abstract}
В кінних заводах та племрепродукторах превентивні заходи щьодо інфекиї, зумовленої герпесвірусами коней першого типу повинні бути комплексними. Необхідно регулярно проводити дегельмінтизації, вітамінізації, застосовувати вірусвакцини, які профілактують масові аборти у кобил і знижують захворювання молодняку респіраторною формою. Застосування препаратів Біомін П.Е.П. та Мікофікс Плюс з розрахунку по 2 гр/100 кг живої маси з проміжком в одну добу протягом 20 діб в місяць протягом одного місяия до та після жереблення сприяє підвищенню резистентності організму коней та зниженню рівня інфікованості герпесвірусною інфекцією першого типу. При регулярному прояві респіраторних хвороб у лошат вакцинацію варто проводити тричі: перший раз - в 10-добовому вічі при наявності нормальної температури тіла в них, наступні - відповідно до інструкиії. Додаткова вакцинація в ранньому віці сприяе блокуванню вакцинним штамом рецепторів клітин, $i$, відповідно, хвороба при виникненні протікає в легкій формі. Основою неспецифічної профілактики герпесвірусної інфекції коней 1 типу є уникнення чи мінімізаиія впливу стресфакторів та імунодепресантів на коней, дотримання ветеринарно-санітарних вимог утримання та годівлі. Схема лікування коней при герпесвірусній інфекції першого типу залежить від форми прояву хвороби і спрямована на запобігання вторинним ускладненням та зменшення симптоматичного прояву захворювання.

Ключові слова: профілактика, лікування, герпесвірусні інфекції, ринопневмонія, коні, вакцинація, антибіотикотерапія, інтерферон, СЕГП, сироватка реконвалесиентів.
\end{abstract}

\section{Лечебно-профилактические мероприятия при герпесвирусной инфекции лошадей первого типа}

\author{
А.Е. Галатюк, В.Л. Бегас \\ halatyuk@mail.ru
}

Житомирский национальный агроэкологический университет,
Старьй бульвар, 7, г. Житомир, 10002, Украина

\begin{abstract}
В конных заводах и племрепродукторах превентивные мероприятия инфекиий, предопределенных герпесвирусамы лошадей первого и второго типов должны быть комплексными. Необходимо регулярно проводить дегельминтизации, витаминизации, применять вирусвакиины, которые профилактируют массовые аборты у кобыл и снижают заболевание молодняка респираторной формой. Применение препаратов Биомин П.Е.П. и Микофикс Плюс из расчёта по 2 гр/100 кг живой массы с промежутком в одни сутки в течение 20 суток в месяи в течение одного месяиа до и после выжеребки способствует повышению резистентности организма лошадей и снижению уровня инфицированности герпесвирусной инфекцией первого типа. При регулярном проявлении респираторных болезней у жеребят вакцинацию необходимо проводить трижды: первый раз - в 10-суточном возрасте при наличии нормальной температуры тела в них, следуюшие, в соответствии с инструкиией. Дополнительная вакцинация в раннем возрасте способствует блокировке вакцинным итаммом рецепторов клеток, и, соответственно, болезнь при возникновении протекает в легкой
\end{abstract}

Citation:

Halatyuk, A., Behas, V. (2016). Therapeutic and prophylactic measures for herpes infections of horses first type. Scientific Messenger LNUVMBT named after S.Z. Gzhytskyj, 18, 3(70), 26-29. 
форме. Основой неспецицфической профилактики герпесвирусной инфекции лошадей 1 типа является избежание или минимизация влияния стресс-факторов и иммунодепрессантов на лочадей, соблюдение ветеринарно-санитарньх требований содержания и кормления. Схема лечения лошадей при герпесвирусной инфекции первого типа зависит от формы проявления болезни и направлена на предотвращение вторичных осложнений и уменьшения симптоматического проявления заболевания.

Ключевые слова: профилактика, лечение, герпесвирусные инфекиии, ринопневмония, лошади, вакцинация, антибиотикотерапия, интерферон, СЕГП, сыворотка реконвалесцентов.

\title{
Therapeutic and prophylactic measures for herpes infections of horses first type
}

\author{
A. Halatyuk, V. Behas \\ halatyuk@mail.ru \\ Zhytomyr national agroecological university, \\ Staryj Boulevard, 7, Zhytomyr, 10002, Ukraine
}

In stud farms and pedigree farms preventive measures of infections, predefined herpesvirus horses of the first types must be complex. It should hold regular deworming, fortification, apply virusvaktsyny that profilaktuyut massive abortions in mares and lower respiratory disease of young form. The use of drugs Biomin P.E.P. and Mikofiks plus the rate of $2 \mathrm{~g} / 100 \mathrm{~kg}$ of live weight with an interval of one day for 20 days per month for one month before and after zhereblennya improves body resistance horses and reduction of infection herpes virus infection, the first type. With regular manifestation of respiratory disease in foals vaccinated should be performed three times: the first time - a 10-day age in the presence of a normal body temperature in them, these - according to the instructions. Additional vaccination at an early age helps blocking vaccine strain receptor cells and, therefore, when a disease occurs in a mild form. At present, Ukraine registered bivalent inactivated vaccine against influenza and herpes infection of horses BioEquin FH and inactivated vaccine against herpes infection of horses BioEquin H, BIOVET, Czech Republic. Both vaccines contain in their composition herpesvirus inactivated horse first type.

The basis for nonspecific prevention of herpes type 1 infection of horses is to avoid or minimize the effects of stress factors and immunosuppressive drugs on horses, compliance with veterinary and sanitary requirements of keeping and feeding. Scheme treat horses with herpes infection depends on the type of the first manifestations of the disease and is aimed at preventing secondary complications and reducing symptomatic manifestations of the disease. In the respiratory form kombiferon injected intramuscularly (recombinant $\dot{\alpha}-$ and $\gamma$-interferon) $-1 \mathrm{~cm}^{3}$ per $100 \mathrm{~kg}$ live weight for 5 days or izamben (amizon) - $1 \mathrm{~g}$ per $100 \mathrm{~kg}$ body weight for 3 days. In the mass outbreaks of respiratory disease in foals good therapeutic effect is serum mares convalescents, which is used subcutaneously at a dose of $0.5-1 \mathrm{~cm}^{3}$ per $1 \mathrm{~kg}$ of live weight for 3 days.

Must conducted one such antibiotic drugs: intramitsyn, penbenks, lincomycin hydrochloride at a dose of $4-5 \mathrm{~cm}^{3} \mathrm{per} 100 \mathrm{~kg}$ live weight for $3-4$ days. The best results can be obtained with the use of antibiotics previously tested on sensitivity to conditionally microflora. After treatment of horses should be exempt from work 7 - 10 days, contributing to a full recovery. If you own inability animals stand, to prevent bedsores, and raise their fixed with supporting band, horses placed between two wooden bars in a box. In symptomatic treatment should also massage the limbs. In the first form of genital conduct inspection of the udder and genitals. In an open cervix, metritis and endometritis presence necessary to lavage the uterus with saline. This once daily should be washed with warm womb of $0.9 \%$ solution of sodium chloride until the solution to that is poured out becomes transparent.

Key words: prophylaxis, treatment, herpesvirus infections, horse, rinopneumonia, vaccination, antibiotic therapy, interferon, SEGP, serum convalescents.

\section{Вступ}

Герпесвірусна інфекція коней 1 типу, незважаючи на повсюдну вакцинацію у світі, навіть сьогодні є великою проблемою конярства (Guanggang, 2012). Системних противірусних лікувальних препаратів при герпесвірусних інфекціях коней не існує. Стратегія лікування спрямована на полегшення прояву клінічних симптомів і запобігання вторинним ускладненням захворювання. Респіраторні інфекції у коней з високою резистентністю, як правило, проходять без лікування і потребують лише належного догляду за тваринами (Starcheus, 1999).

Основні цілі терапії такі: зменшити клінічні ознаки вірусної інфекції, зупинити гідратацію і забезпечити щоденні калорійні потреби хворих тварин, зменшити ускладнення, що виникають через бактеріальні суперінфекції, чи шляхом попередження генералізації інфекції за межами дихальних шляхів. Дві головні задачі при неускладненій ринопневмонії - антипіретія і застосування нестероїдних протизапальних препаратів для запобігання запалення дихальних шляхів (Cutler and MacKay, 1997).

Для коней з паралічем, зумовленим ГВК-1, використовують диметилсульфоксил (3 $\left.\mathrm{cm}^{3} / \kappa \Gamma\right)$ разом 3 парентеральним кортикостероїдом (дексаметазон 0,1 мг/кг). Коням з паралічем сечового міхура чи його сфінктера, що пов'язані з нервовим проявом ринопневмонії, необхідна постійна сечова катетеризація, посткатетерне промивання сечового міхура розчинами антибіотиків, лікування циститу. При певних клінічних випадках (ГВК-1 неонатальна інфекція жеребців, рання стадія спалаху ГВК-1 аборту чи мієлоенцефалопатія і т.д.) використовують препарати антивірусної хіміотерапії, наприклад ациклічні нуклеотидні аналоги (ацикловір, валацикловір), які є дорогими і тому можуть застосовуватися для лікування окремих цінних тварин (Wilkins et al., 2003).

Найбільш дієвим профілактичним заходом є поділ коней на невеликі групи 3 наступним утриманням i 
обслуговуванням кожної групи як ізольованого цілого; запобігання стресам (Bryans, 1981). Групи підбирають за віком, статтю, використанням і частотою переміщення окремої тварини. Жеребних кобил потрібно вчасно ізольовувати, не утримувати їх разом 3 нежеребними, особливу увагу слід приділяли тваринам, що будуть вперше жеребитись. Велику небезпеку для групи являють нові тварини, які недавно піддались можливому інфікуванню при продажі, шоу, скачках, змаганнях, тренуваннях, а також при змішуванні різних груп коней. Тобто, перед введенням в групу нового коня потрібна мінімальна 21-добова ізоляція.

Метою нашої роботи було удосконалення методів лікування та профілактики герпесвірусних інфекцій першого типу у коней. Для цього були поставленні такі завдання: розробити лікування респіраторної, нервової та генітальної форм герпесвірусної інфекції першого типу, а також удосконалити профілактичні заходи.

\section{Матеріал і методи досліджень}

Досліди були проведені на конях різних вікових і породних груп з кінних господарств України (260 голів, в 2010 - 2015 роках). Епізоотологічний метод досліджень проводився за загальноприйнятими підходам (Dzhupina and Kolosova, 1991; Jarchuk et al., 2002). Для підтвердження діагнозу в РЗГА та РДП був використаний герпесвірус коней першого типу (штам «ГВК-1 Ж»). Дослідження проводили у відповідності з методичними рекомендаціями: Діагностика герпесвірусної інфекції першого та другого типу у коней (Galatjuk et al., 2009).

\section{Результати та їх обговорення}

Внаслідок проведення цілого ряду експериментальних досліджень, нам вдалось удосконалити лікувально-профілактичні заходи при інфекціях коней, зумовлених ГВК 1 типу.

1. При респіраторній формі слід внутрішньовенно вводити розчин такого складу: $300 \mathrm{~cm}^{3}$ 3\%ного розчину норсульфазолу натрію, $200 \mathrm{~cm}^{3} 40 \%$ ної глюкози, $100 \mathrm{~cm}^{3}$ етилового спирту, $20 \mathrm{~cm}^{3}$ кофеїну протягом $3-4$ діб. Добрий лікувальний ефект можна отримати при застосуванні розробленого нами препарату СЕГП (Патент 36030 А, Україна), що містить такі складники: сульфаніламіди, спирт, глюкоза, прополіс. Препарат вводиться внутрішньовенно в дозі 0,5 $\mathrm{cm}^{3}$ на 1 кг живої маси протягом 3 4-х діб. Додатково при високій температурі внутрішньом'язово слід вводити диклоберл або вольтарен в дозі 3,5-4 $\mathrm{cm}^{3}$ на 100 кг живої маси протягом 2 4-х діб. Внутрішньом'язово вводять комбіферон (рекомбінантні $\alpha-$ та $\gamma$-інтерферони) $-1 \mathrm{~cm}^{3}$ на 100 кг живої маси протягом 5-ти діб або ізамбен (амізон) - 1 г на 100 кг живої маси протягом 3 діб. При масових спалахах респіраторних хвороб у лошат добрий лікувальний ефект дає сироватка кобил реконвалесцентів, яку застосовують підшкірно в дозі $0,5-1 \mathrm{~cm}^{3}$ на 1 кг живої маси протягом 3-х діб.
Обов'язково проводиться антибіотикотерапія одним 3 таких препаратів: інтраміцин, пенбенкс, лінкоміцину гідрохлорид в дозі $4-5 \mathrm{~cm}^{3}$ на 100 кг живої маси протягом $3-4$ діб. Кращі результати можна отримати при застосуванні антибіотиків попередньо протестованих щодо чутливості до умовнопатогенної мікрофлори. Протягом 3 - 4 діб один раз на добу застосовували аерозолі бальзаму «в'єтнамська зірочка» 3 експозицією 20 - 30 хвилин. Після проведення лікування коней слід звільнити від роботи на 7 - 10 діб, що сприяє їх повному одужанню. При нехтуванні цим правилом відмічалися рецидиви хвороби.

2. При нервовій формі необхідно застосовувати внутрішньовенно розчин такого складу: $200 \mathrm{~cm}^{3}$ $40 \%$ глюкози, 20 - $30 \mathrm{~cm}^{3} 20 \%$ кофеїну, $5-6 \mathrm{~cm}^{3}$ лазікса. Крім того внутрішньом'язово вводять 20 $25 \mathrm{~cm}^{3}$ пірацетаму протягом $4-5$ діб. Підшкірно вітаміни $\mathrm{B}_{2}, \mathrm{~B}_{6}$, прозерин або аміридин протягом 5 7 діб в загальноприйнятих дозах. Додатково при необхіднлсті вводять вищевказані антибіотики протягом $3-4$ діб. При нездатності тварин самостійно стояти, для профілактики пролежнів, їх підіймають та фіксують за допомогою підтримуючих шлей, коней розміщують між двома дерев'яними брусками у деннику. Крім симптоматичного лікування показаний також масаж кінцівок.

3. При генітальній формі спершу проводять обстеження вимені та статевих органів. При відкритій шийці матки, наявності метритів та ендометритів необхідно провести промивання матки фізіологічним розчином. При цьому один раз на добу слід промивати матку теплим $0,9 \%$ розчином кухонної солі до поки розчин, що виливається, не стане прозорим (вводять по $3-4$ л). Після цього застосовують $3-4$ внутрішньоматкові палички. Також слід застосувати в загальноприйнятих дозах прозерин чи аміридин, тетравіт, катозал $2-3$ рази з інтервалом 2 - 3 доби. При гнійному ендометриті слід застосувати антибіотики, чутливість мікрофлори до яких доцільно встановити в лабораторії.

Неспецифічна профілактика. Основою неспецифічної профілактики герпесвірусної інфекції коней 1 типу $є$ уникнення скупченого утримання коней. Ідеальним $є$ варіант індивідуального утримання тварин 3 мінімальним контактом між ними. Необхідно приділяти особливу увагу виконанню комплексу профілактичних заходів, направлених на недопущення у жеребних кобил стресів й інших несприятливих факторів. Практичні спостереження й результати власних розробок свідчать про те, що в господарствах, де для конематок використовують збалансований кормовий раціон, багатий вітамінами, регулярно проводиться профілактика гельмінтозів, вітамінізація на $10-11$ місяцях жеребності, конематок випасають до грудня місяця, масове жереблення відбувається в січні-березні, а в стійловий період жеребні кобили перебувають у левадах не менше 3 - 4 годин на добу, аборти на 8,5 - 11 місяцях жеребності та масові респіраторні хвороби проявляються рідко й не завдають значного економічного збитку. 
3 метою підвищення резистентності організму кобил та зниженню рівня інфікованості герпесвірусною інфекцією першого типу доцільно задавати разом із концентрованими кормами препарати Біомін П.Е.П. та Мікофікс Плюс 3 розрахунку по 2 гр/100 кг. ж. м. 3 проміжком в одну добу протягом 20 діб в місяць протягом одного місяця до та після жереблення. Для профілактики клінічного прояву хвороби кобил на 8 - 10 міс жеребності забезпечують пророщеним зерном (0,5 кг на голову).

Специфічна профілактика. Участь у проведенні оздоровчих заходів та практичні спостереження свідчать про те, що при наявності ринопневмонії в господарстві необхідно щорічно проводити вакцинацію поголів'я. При регулярному прояві респіраторних хвороб у лошат вакцинацію варто проводити тричі: перший раз - в 10-добовому віці при наявності нормальної температури тіла в них, наступні відповідно до інструкції. Додаткова вакцинація в ранньому віці сприяє блокуванню вакцинним штамом рецепторів клітин, i, відповідно, хвороба при виникненні протікає в легкій формі. Лошат, у яких підвищена температура тіла, лікують і після одужання вакцинують. Своєчасна імунізація в більшості випадків дає змогу запобігти клінічним проявам хвороби і підвищує збереження лошат. Вакцинація проти герпесвірусної інфекції 1 типу є обов'язковою для всіх спортивних коней, інакше вони не будуть допущені до змагань. Обов'язково треба прищеплювати племінних тварин, особливо кобил, оскільки герпесвірус 1 типу - це одна 3 найвірогідніших причин абортів в другій половині жеребності.

Раніше на території України застосовували вакцину проти ринопневмонії коней: «Вакцина против ринопневмонии лошадей $\mathrm{CB}-69$ » виробництва Щолковської біофабрики (Росія). До недавнього часу в Україні не було зареєстрованих вакцин щодо герпесвірусної інфекції першого типу. Наразі в Україні зареєстровані бівалентна інактивована вакцина проти грипу і герпесвірусної інфекції коней БіоЕквін FH та інактивована вакцина проти герпесвірусної інфекції коней БіоЕквін Н (BioEquin FH, BioEquin H, БIOBET, Чеська республіка). Обидві вакцини в своєму складі містять інактивований герпесвірус коней першого типу. На світовому ринку представлений широкий спектр вакцин щодо герпесвірусних інфекцій 1 і 4 типу: Rhinomune (EHV-1) Equine Vaccine (Boehringer Ingelheim) Calvenza-03 EIV/EHV (Rhino + Flu) (Boehringer Ingelheim), Duvaxin EHV-1,4 (Fort Dodge); Пневмеквін (Merial); Equivac $\AA$ EHV-1/4 (Fort Dodge, USA); FluVac Innovator ${ }^{\circledR}$ EHV-4/1 (Fort Dodge); Pneumabort K + 1B (Fort Dodge); Prestige ${ }^{\circledR}$ w/ Havlogen ${ }^{\circledR}$ (Intervet); Prodigy ${ }^{\circledR}$ Rhino Shot (Intervet); Equilis Resequin (Intervet). Частина 3 них спрямована на профілактику респіраторних проявів і вони мають в своєму складі ГВК 1 типу або ГВК-1/4 типів, деякі 3 них спрямовані на профілактику тільки абортів. Однак рівень напруженості імунітету, який вони створюють не вивчений в Україні, а це обов'язково необхідно знати і врахувати при проведенні їх реєстрації.

\section{Висновки}

1. В кінних заводах та племрепродукторах превентивні заходи інфекцій, зумовлених ГВК-1 типу повинні бути комплексними. Необхідно регулярно проводити дегельмінтизації, вітамінізації, застосовувати вірусвакцини, які профілактують масові аборти у кобил і знижують захворювання молодняку респіраторною формою.

2. Застосування препаратів Біомін П.Е.П. та Мікофікс Плюс $з$ розрахунку по 2 гр/100 кг. ж. М. 3 проміжком в одну добу протягом 20 діб в місяць протягом одного місяця до та після жереблення сприяє підвищенню резистентності організму кобил та зниженню рівня інфікованості герпесвірусною інфекцією першого типу.

Перспективи подальших досліджень. В подальшому планується удосконалювати схеми лікування та профілактики герпесвірусних інфекцій першого типу шляхом вивчення нових препаратів, які підвищують резистентність організму коней.

\section{Бібліографічні посилання}

Guanggang, Ma. (2012). Equine Herpesvirus Type 1: Immune Evasion and Vector Development: Inaugural-Dissertation. Free University of Berlin, 90.

Starcheus, A.P. (1999). Gerpesvirusy konej. Tvarynnycztvo Ukrayiny. 3-4, 20-22 (in Ukrainian).

Cutler, T.J., MacKay, R.J. (1997). Equine herpesvirus-1 myeloencephalitis. Current therapy in equine medicine. - Philadelphia WB Saunders Co. 333-335.

Wilkins, P.A., Henninger, R., Reed, S.M., Del, F. Piero, A. (2003). Acyclovir as Treatment for EHV-1 Myeloencephalopathy. 49th Annual Convention of the American Association of Equine Practitioners, New Orleans, Louisiana.

Bryans, J.T. (1981). Application of management procedures and prophylactic immunization to the control of equine rhinopneumonitis. In Proceedings of the 26th Annual Conference of the American Association of Equine Practitioners, Anaheim. 26, 259-272.

Dzhupina, S.I., Kolosova, A.A. (1991). Metody jepizootologicheskih issledovanij: metod. Rekomendacii. RASHN, Sib. otd-nie IJeVSiDV. Novosibirsk, 60 (in Russian).

Jarchuk, B.M., Verbyc'kyj, P.I., Lytvyn, V.P., Kornijenko, L.Je., Dombrovs'kyj, O.B., Tyrsin, R.V., Kornijenko, L.V. (2002). Zagal'na epizootologija. B.C. BDAU. 324 566 (in Ukrainian).

Galatjuk, O.Je., Begas, V.L., Kan'ovs'kyj, A.I., Radzyhovs'kyj, M.L., Antonjuk, A.A., Abramov, A.V., Aljeksjejeva, G.B., Sabachova, M.A., Sinicyn, V.A., Grubich, P.Ju., Verbyc'kyj, P.I., Gorzhejev, V.M., Gnap L.K. (2009). Diagnostyka gerpesvirusnoi' infekcii' pershogo ta drugogo typu u konej: metodychni rekomendacii'. Zhytomyr. 22 (in Ukrainian).

Стаття надійшла до редакиії 23.09.2016 